\title{
Delayed presentation of cauda equina syndrome secondary to lumbar disc herniation: functional outcomes and health-related quality of life
}

\author{
Jason W. Busse, DC; $* \dagger$ Mohit Bhandari, MD; †† Joseph B. Schnittker, MD; $\S$ Kesava Reddy, MD; $\S$ \\ R. Brett Dunlop, MD
}

\begin{abstract}
Objective: Cauda equina syndrome (CES) is a feared complication of lumbar disc herniation. It is generally accepted that CES requires decompression within 6 hours of symptom onset, but this time goal is rarely met, and the relative benefit of delayed decompression on functional status and quality of life (QOL) remains unknown. The study objective was to describe the functional status and quality of life outcomes for patients who undergo delayed surgical decompression for CES.

Methods: Patients with CES who underwent decompression of a herniated lumbar disc during a 10 -year period were assessed at hospital discharge and at least 4 months after the procedure. Evaluation of functional outcomes was based on a previously validated scale and QOL outcomes on the Medical Outcomes Study 36-item Short-Form Health Survey (SF-36) questionnaire.

Results: During the study period, 1100 patients with herniated discs were identified, and 14 underwent surgical decompression for CES. All 14 had had symptoms for more than 38 hours before surgery. Ten patients were available for long-term follow-up. There was a strong correlation between long CES symptom duration and poor functional outcome: of 8 patients with symptoms for less than 10 days before decompression (range, 1.6-7.5 d), all had good functional outcomes. The 2 patients with more prolonged symptoms (10.6 and $14.2 \mathrm{~d}$ ) had poor outcomes. SF-36 scores demonstrated declines in physical roles $(p=0.03)$, social function $(p=0.03)$ and increased pain $(p$ $=0.003$ ) compared with population norms. Correlation between SF-36 domain scores and CES symptom duration failed to achieve statistical significance, perhaps because of small sample size. Conclusions: Patients who undergo delayed decompression for CES have increased pain and impaired social and physical function. Longer delays correlate with worse functional outcomes. Beyond 24 hours, decompression delay may be associated with a poorer quality of life but, because of the rarity of CES, the sample size in this study was too small to provide definitive conclusions. Since no patients underwent surgery within 38.4 hours of symptoms, it is not possible to comment on the importance of emergent decompression in early presenters.
\end{abstract}

\section{RÉSUMÉ}

Objectif : Le syndrome de la queue de cheval (SQC) est une complication redoutée de I'hernie discale lombaire. Il est généralement reconnu que ce syndrome nécessite une décompression dans les six heures suivant l'apparition des symptômes, mais ce délai-cible est rarement respecté et les bienfaits relatifs d'une décompression retardée du point de vue fonctionnel et de la qualité de vie demeurent inconnus. L'objectif de cette étude était de décrire le devenir de patients soumis à une

\footnotetext{
*Oncidium Health Group Inc., Burlington, Ont.; †Department of Clinical Epidemiology and Biostatistics, $\neq$ Department of Orthopaedics, and
} §Division of Neurosurgery, McMaster University, Hamilton, Ont.

Received: Mar. 6, 2001; final submission: July 4, 2001; accepted: July 10, 2001

This article has been peer reviewed. 
décompression retardée pour un SQC quant à leur état fonctionnel et à leur qualité de vie.

Méthodes : Des patients atteints d'un SQC ayant subi une décompression d'une hernie discale lombaire au cours d'une période de dix ans furent évalués au moment de recevoir leur congé de l'hôpital et au moins quatre mois après l'intervention. L'évaluation des résultats quant à l'état fonctionnel était basée sur une échelle validée auparavant et celle des résultats quant à la qualité de vie était basée sur le questionnaire Medical Outcomes Study 36-item Short-Term Health Survey (SF-36). Résultats: Au cours de la période d'étude, 1100 patients souffrant d'une hernie discale furent identifiés et 14 d'entre eux subirent une décompression chirurgicale pour un SQC. Les 14 patients présentaient leurs symptômes depuis plus de 38 heures avant la chirurgie. Dix patients étaient disponibles pour un suivi à long terme. II y avait une forte corrélation entre la durée des symptômes du SQC et un mauvais résultat quant à l'état fonctionnel : parmi huit patients ayant eu des symptômes pendant moins de dix jours avant la décompression (éventail, 1,6-7,5 jours), tous eurent un résultat satisfaisant. Les deux patients dont les symptômes duraient depuis plus longtemps (entre 10,6 et 14,2 jours) eurent de mauvais résultats. Les scores du questionnaire SF-36 démontraient une diminution des capacités physiques $(p=0,03)$, des fonctions sociales $(p=0,03)$ et une augmentation de la douleur $(p=0,03)$ par rapport à des sujets normaux. La corrélation entre les scores du questionnaire SF-36 et la durée des symptômes du SQC n'atteignit pas un niveau statistiquement significatif, peut-être en raison de la petite taille de l'échantillon.

Conclusions : Les patients qui reçoivent une décompression retardée pour un SQC ressentent une plus grande douleur et voient leur fonctionnement physique et social se détériorer. Des délais plus longs sont associés à des résultats encore plus négatifs du point de vue fonctionnel. Après 24 heures, le retard pour la décompression peut être associé à une moins bonne qualité de vie, mais en raison de la rareté de ce syndrome, la taille de l'échantillon pour cette étude était trop petit pour arriver à des conclusions définitives. Comme aucun patient ne fut soumis à la chirurgie dans les 38,4 heures suivant l'apparition de ses symptômes, il est impossible de commenter sur l'importance d'une décompression d'urgence chez les patients vus peu de temps après l'apparition de leurs symptômes.

Key words: cauda equina syndrome; intervertebral disc herniation; quality of life

\section{Introduction}

Cauda equina syndrome (CES) is a rare but serious condition occurring in approximately $1 \%$ to $3 \%$ of patients with herniated lumbar discs. Symptoms include dull, aching, low back pain, generally radiating in a sciatic distribution, with associated paresthesias, areflexic paralysis, and bowel or bladder dysfunction due to spinal nerve root compression. ${ }^{1}$ CES represents a true surgical emergency mandating urgent decompression. ${ }^{2}$ It is generally accepted that surgery should be performed within 6 hours of symptom onset in order to minimize neurologic deficit; ${ }^{3}$ however, this is seldom achieved. To our knowledge, no study has yet evaluated long-term clinical outcomes following surgical decompression for CES, and the correlation of patient outcome with the timing of decompression remains contro-

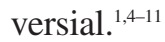

Our objective was to describe functional and quality of life outcomes for patients who underwent delayed surgical decompression for CES. Our hypothesis was that patients with delayed decompression of CES would exhibit significantly worse functional outcomes and quality of life scores than age- and gender-matched norms.

\section{Methods}

\section{Setting and patients}

This study was carried out at the Hamilton Health Sciences Corporation-General Hospital, a university-affiliated teaching hospital in Hamilton, Ont. Patients were eligible for inclusion if they had a clinical presentation compatible with CES, a herniated lumbar disc, and subsequent surgical decompression.

\section{Data collection}

We searched our hospital's health records database to identify all patients treated for a herniated lumbar disc during a 10-year period from 1985 to 1995 . Trained abstractors (JB, MB) then reviewed a hard copy of patient charts to identify patients who had lumbar disc herniation and underwent laminectomy for symptoms of CES. For a patient to qualify as having CES, his or her chart required documentation of the following 3 elements: low back pain with sciatic radiation; paresthesias and signs of areflexic paralysis; and bowel or bladder dysfunction. Disc herniation and levels of involvement were confirmed by magnetic resonance imaging (MRI) or computed tomography 
(CT). Data were gathered in standardized fashion and recorded on specific study forms.

\section{Clinical stratification}

On the basis of their clinical presentation, the patients were assigned to groups, as defined by Tandon and Sankaran. ${ }^{12}$ Group I patients had a sudden onset of CES with no prior low back complaints; Group II patients had recurrent previous episodes of low back pain or sciatica and an index episode of CES; and Group III patients presented with low back pain and bilateral sciatica that gradually progressed to CES. ${ }^{12}$

\section{Follow-up and functional outcomes}

Functional outcomes were evaluated at the time of discharge from hospital and at least 4 months after surgery by an assessor blinded to surgical delay category. Based on the strategy proposed by Epstein and Hood, ${ }^{13}$ the outcome assessor allocated patients into one of 4 outcome groups. Group 1 (poor outcome) patients experienced no improvement in neurologic function or had an increased deficit that required medication (including opioids) for chronic pain. Group 2 (fair outcome) patients demonstrated mild neurologic improvement with moderate residual pain, and required consistent medication for pain. Group 3 (good outcome) patients demonstrated moderate neurologic improvement with a mild residual deficit and minimal medication use for pain. Group 4 (excellent outcome) patients demonstrated complete resolution of their baseline neurologic deficit(s) and required no medication. These outcomes were evaluated at the time of discharge from hospital and on the individual's last postoperative followup visit.

\section{Health-related quality of life}

At the time of the follow-up visit, patients were also asked to complete the Medical Outcomes Study (MOS) 36-item Short-Form Health Survey (SF-36) QOL questionnaire. The SF-36 has been used in surgical outcome studies and validated in spine surgery populations. ${ }^{5,13-16}$ Its 8 domains are: physical function, social function, role physical, role emotional, mental health, energy, bodily pain and general health, which can be converted to a score from $0 \%$ to $100 \%{ }^{10,11}$ To enhance understanding and optimize item response rate, the SF-36 was self-administered in the presence of a blinded interviewer.

SF-36 scores were tabulated and compared with established population norms by subtracting expected score (age- and gender-matched normative data) from the patient's actual score to calculate a difference score. For example, patient 1, a 41-year-old male, reported a physical function score of 35, but the normative score for a 41-yearold North American male is 91.39; therefore, the difference score is -56.39 (Table 1). A difference score of zero indicates a perfect match with the normative data, a difference score below zero indicates that the patient's reported SF-36 domain is worse than the average North American, and a score greater than zero indicates that the patient perceives themselves as having better than average QOL in the specified SF-36 domain.

\section{Statistics}

The statistical significance of observed differences between actual and expected SF-36 domain scores was determined using a two-tailed Student's $t$-test. Correlation between surgical outcome category and surgical delay time was determined using the Spearman correlation coefficient. Correlation between SF-36 patient scores and surgical delay was determined using the Pearson correlation coefficient. For all comparisons, a $p$ value $<0.05$ was considered statistically significant.

\begin{tabular}{|c|c|c|c|c|c|c|c|c|c|}
\hline \multirow[b]{2}{*}{ Patient } & \multirow{2}{*}{$\begin{array}{l}\text { Symptom } \\
\text { duration, d }\end{array}$} & \multicolumn{2}{|c|}{ Function } & \multicolumn{2}{|c|}{ Role } & \multirow[b]{2}{*}{ Energy } & \multirow[b]{2}{*}{ Pain } & \multicolumn{2}{|c|}{ Health } \\
\hline & & Physical & Social & Physical & Emotional & & & Mental & General \\
\hline 1 & 1.6 & -56.39 & -63.54 & -89.76 & -85.52 & -25.50 & -79.36 & -24.98 & -52.55 \\
\hline 2 & 1.8 & 6.94 & 16.93 & 16.35 & 19.92 & 15.57 & -13.85 & 18.68 & 25.75 \\
\hline 3 & 3.75 & -8.39 & -13.54 & -64.76 & 14.48 & 19.50 & -38.36 & -0.98 & -2.55 \\
\hline 4 & 4.8 & 8.50 & -10.54 & -10.58 & -18.42 & 21.95 & -2.18 & -0.38 & -6.16 \\
\hline 5 & 5.0 & -51.39 & -63.54 & -89.76 & -85.52 & -35.50 & -48.36 & -36.98 & -35.55 \\
\hline 6 & 5.2 & -5.89 & -29.66 & 15.28 & -9.94 & -22.80 & -27.76 & -25.37 & -13.62 \\
\hline 7 & 7.2 & 3.61 & 11.46 & 10.24 & 14.48 & 4.50 & 4.64 & 19.02 & -5.55 \\
\hline 8 & 7.5 & -18.06 & 4.93 & -8.65 & 19.92 & 10.57 & -22.85 & 18.68 & 3.75 \\
\hline 9 & 10.6 & -69.12 & -71.06 & -86.73 & -82.32 & -53.04 & -67.61 & -60.45 & -63.58 \\
\hline 10 & 14.2 & -4.12 & -46.06 & -61.73 & 17.68 & 11.96 & -38.61 & -0.45 & 0.20 \\
\hline Mean & 6.2 & -19.4 & -26.4 & -37.0 & -19.5 & -5.3 & -33.4 & -9.3 & -15.0 \\
\hline$p$ & & 0.06 & 0.03 & 0.03 & 0.20 & 0.55 & 0.003 & 0.30 & 0.12 \\
\hline
\end{tabular}




\section{Results}

During the 10-year study period, 1100 patients with herniated lumbar discs were identified in the hospital health records database. Of these, 14 (1.3\%) met our inclusion criteria, with clinical findings of CES and surgical decompression of documented prolapsed disc. Table 2 shows that the study cohort included 8 men and 6 women with a mean age of 41.8 years (range from 25-69 yr). Mean time from symptom onset to hospital presentation was 5.3 days (range from 1-14 d), and time from presentation to surgery was 0.85 days (range from $0.2-1.75 \mathrm{~d}$ ). Average total duration of CES symptoms prior to decompression was 6.19 days (range from 1.6-14.3 d).

\section{Functional outcomes}

Table 2 shows that, at the time of hospital discharge, 9 patients were assessed as having good outcomes, whereas 1 was considered to have a fair outcome and 4 were assessed as having poor outcomes. No outcomes were considered excellent. At a mean follow-up time of 2.1 years after surgery (range from 4-68 mo), 1 patient had died and 3 could not be reached, leaving 10 in the follow-up group, including 6 men and 4 women. At this time, 1 patient from the "poor" outcome group and 1 from the "fair" group had moved into the "good" category, leaving a total of 8 patients with good outcomes and 2 with poor outcomes. Again, no outcomes were considered excellent.

\section{Clinical outcomes and surgical delay}

All 8 patients with CES symptom durations between 1.6 and 7.5 days ultimately had good functional outcomes, although the patient in this group with the longest symptom duration $(7.5 \mathrm{~d})$ fell into the "poor" outcome group at the time of hospital discharge. Both patients whose CES symptom duration was over 10 days (10.6 and $14.2 \mathrm{~d}$ ) prior to decompression had poor outcomes at discharge and at follow-up (Table 2). Consequently, there was a strong correlation between CES symptom duration and poor functional outcome, both at discharge (Spearman $r=0.83, p=0.003$ ) and at long-term follow-up $(r=0.70, p=0.025)$.

\section{Quality of life}

Table 1 shows that SF-36 scores in the follow-up group demonstrated declines in all domains except mental health and energy, although these declines only achieved statisti-

Table 2. Patient demographics, clinical presentation and functional outcomes

\begin{tabular}{|c|c|c|c|c|c|c|}
\hline \multirow[b]{2}{*}{ Patient } & \multirow[b]{2}{*}{$\begin{array}{l}\text { Gender, } \\
\text { age }\end{array}$} & \multirow[b]{2}{*}{$\begin{array}{l}\text { Duration } \\
\text { of CES, } d\end{array}$} & \multirow[b]{2}{*}{ Symptoms at presentation } & \multicolumn{2}{|c|}{ Outcome group } & \multirow[b]{2}{*}{$\begin{array}{l}\text { Follow- } \\
\text { up, mo }\end{array}$} \\
\hline & & & & $\begin{array}{c}\text { At } \\
\text { discharge }\end{array}$ & $\begin{array}{l}\text { At } \\
\text { follow- } \\
\text { up }\end{array}$ & \\
\hline 1 & M, 41 & 1.6 & $\begin{array}{l}\text { Unilateral sciatica, saddle anesthesia, urinary sphincter } \\
\text { incontinence, motor weakness }\end{array}$ & Good & Good & 4 \\
\hline 2 & $\mathrm{~F}, 35$ & 1.8 & $\begin{array}{l}\text { Unilateral sciatica, saddle anesthesia, urinary sphincter } \\
\text { incontinence, reflexes decreased }\end{array}$ & Good & Good & 67 \\
\hline 3 & M, 39 & 3.75 & $\begin{array}{l}\text { Bilateral sciatica, saddle anesthesia, urinary sphincter } \\
\text { incontinence, motor weakness, reflexes decreased }\end{array}$ & Good & Good & 4 \\
\hline 4 & M, 49 & 4.8 & Saddle anesthesia, motor weakness, reflexes decreased & Good & Good & 40 \\
\hline 5 & M, 42 & 5 & Unilateral sciatica, saddle anesthesia, motor weakness & Good & Good & 22 \\
\hline 6 & M, 69 & 5.2 & $\begin{array}{l}\text { Unilateral sciatica, saddle anesthesia, anal \& urinary } \\
\text { sphincter incontinence, motor weakness }\end{array}$ & Fair & Good & 10 \\
\hline 7 & M, 42 & 7.2 & Saddle anesthesia, anal \& urinary sphincter incontinence & Good & Good & 68 \\
\hline 8 & $F, 37$ & 7.5 & $\begin{array}{l}\text { Unilateral sciatica, saddle anesthesia, urinary sphincter } \\
\text { incontinence }\end{array}$ & Poor & Good & 12 \\
\hline 9 & $\mathrm{~F}, 25$ & 10.6 & $\begin{array}{l}\text { Unilateral sciatica, saddle anesthesia, anal \& urinary } \\
\text { sphincter incontinence, motor weakness, reflexes } \\
\text { decreased }\end{array}$ & Poor & Poor & 11 \\
\hline 10 & $F, 34$ & 14.2 & Saddle anesthesia, anal \& urinary sphincter incontinence & Poor & Poor & 14 \\
\hline 11 & M, 56 & 3 & $\begin{array}{l}\text { Bilateral sciatica, urinary sphincter incontinence, motor } \\
\text { weakness, reflexes decreased }\end{array}$ & Good & Died & $\mathrm{n} / \mathrm{a}$ \\
\hline 12 & $F, 33$ & 3 & $\begin{array}{l}\text { Unilateral sciatica, saddle anesthesia, urinary sphincter } \\
\text { incontinence, motor weakness, reflexes decreased }\end{array}$ & Good & Lost & $\mathrm{n} / \mathrm{a}$ \\
\hline 13 & M, 34 & 4.7 & $\begin{array}{l}\text { Bilateral sciatica, saddle anesthesia, urinary sphincter } \\
\text { incontinence, motor weakness, reflexes decreased }\end{array}$ & Good & Lost & $\mathrm{n} / \mathrm{a}$ \\
\hline 14 & $F, 49$ & 14.3 & $\begin{array}{l}\text { Bilateral sciatica, saddle anesthesia, anal \& urinary } \\
\text { sphincter incontinence, motor weakness }\end{array}$ & Poor & Lost & $\mathrm{n} / \mathrm{a}$ \\
\hline
\end{tabular}


cal significance for role physical ( $p=0.03$ ), social function $(p=0.03)$ and increased bodily pain $(p=0.003)$ when compared to age- and gender-matched population norms. Pearson correlation between any of the 8 SF-36 health scales and CES symptom duration prior to decompression failed to achieve statistical significance, perhaps due to the small sample size.

\section{Discussion}

Cauda equina syndrome is an uncommon complication of multiple extradural space-occupying lesions, ${ }^{17-20}$ most often intervertebral disc protusions. ${ }^{2}$ Central lumbar rupture causes compression of the sacral roots of the cauda equina in $1 \%$ to $15 \%$ of all herniations. ${ }^{3,14,21-24}$ Symptomatic disc herniation is most common in patients between 30 and 50 years of age ${ }^{25}$ but, because fewer than $10 \%$ of herniated discs occur above the L4-5 level, disc herniation resulting in CES does not usually involve the spinal cord. ${ }^{26}$

Pathognomonic signs of CES include bowel and bladder dysfunction (with retention or incontinence) and saddle paraesthesia, but the classic presentation is uncommon; therefore, acute onset of any of these signs warrants further investigation. MRI is the preferred investigation because it visually confirms the diagnosis and establishes the level of disc protrusion..$^{27}$ Discectomy is the treatment of choice, but carries a failure rate of $10 \%$ to $20 \% .^{28,29}$

Even for seasoned clinicians, CES represents a diagnostic challenge. Classic teaching is that time to decompressive surgery is critical. This concept has been reinforced by malpractice claims initiated against physicians in cases where delay was associated with a poor outcome. ${ }^{14}$ Consequently, great efforts are expended to triage patients with CES to facilities where spinal surgery is performed. It is generally accepted that surgery should be performed within 6 hours of symptom onset;, ${ }^{2,14,30,31}$ however, this goal may be more academic than pragmatic, and $85 \%$ or more of CES patients have symptoms exceeding 48 hours before they receive decompression surgery. ${ }^{14}$ This finding was confirmed in the present study.

There are relatively few published studies on CES and most of these had small sample sizes. . $^{3,12,1,14,17,21-23,30,32-39} \mathrm{~A}$ recent meta-analysis ${ }^{4}$ demonstrated improved outcomes when CES patients were treated within 48 hours, but this meta-analysis included only observational studies, thereby limiting the strength of its conclusions..$^{40,41}$

Using animal models of CES, Sayegh and colleagues ${ }^{2}$ found no differences in neurologic outcomes with early versus delayed intervention, but better recovery times for somatosensory evoked potentials (SEP). Although they dealt with compression times of less than 60 minutes and noted changes only in a surrogate marker (SEP), their conclusions emphasized the importance of early decompression. Other investigators ${ }^{1}$ found no difference in neurologic recovery, histopathology or SEPs in a dog model of incomplete cauda equina compression, regardless of whether decompression occurred 1 hour or 1 week after onset of compression.

In a retrospective review of 31 patients, Kostiuk and coworkers $^{3}$ found no correlation between neurologic recovery and decompression delay over a range of hours to weeks. Other investigations have reported similar findings. ${ }^{21,32}$ Some investigators have found that the clinical syndrome at time of presentation is of more prognostic significance than time to decompression, ${ }^{12}$ and the results of the present study support this conclusion.

In this study, although the numbers were small, only patients with longer than 10 days of symptoms prior to decompression had poor outcomes. All those with symptoms up to 7.5 days in duration had good outcomes, which goes against the traditional view that CES is a neurosurgical emergency requiring treatment within 6 hours. Because no patient with CES underwent surgery within 38.4 hours of symptom onset, we cannot comment on the benefit or lack of benefit of emergent decompression during this early period. Other factors such as age, concomitant litigation and workers' compensation status are known to influence recovery after back surgery. ${ }^{42,43}$ Because there were no such patients in this study, we cannot assess the impact of these factors.

QOL is a critical outcome measure, but the best way to measure it is unclear. ${ }^{44-46}$ Lang and associates ${ }^{5}$ and Epstein and Hood ${ }^{13}$ found that, after complex neurosurgery and lateral lumbar disc surgery, surgeon-assessed outcomes correlated poorly with SF-36 scores, and that surgeons underestimated the impact of neurosurgery on patient QOL. These findings suggest that the SF-36 is a more sensitive and discriminating indicator of clinically important surgical sequelae as relates to QOL, although it has not been previously validated in patients with CES. Like these other studies, our data suggest that the SF-36 may be more sensitive than surgical assessment, and that patients with "good" surgical outcomes do not always rate their QOL as high. Indeed, our sample demonstrated significant declines in 3 SF-36 domains (role physical, social function and bodily pain) relative to age- and gender-matched population norms.

Late referral accounted for the majority of delays to decompressive surgery in our study. Despite the fact that we failed to demonstrate a benefit of early decompression, physicians should remain vigilant for CES in patients with suggestive symptoms. 
Our findings should be validated by a prospective study involving more patients, but given the rarity of CES and the inability to randomize patients to emergent versus urgent decompression, it is unlikely this question will be definitively answered.

\section{Conclusion}

Our data suggest that good outcomes are likely after CES, except in patients with very prolonged decompression delays ( $>7 \mathrm{~d})$. This study questions the traditional view that CES is always a neurosurgical emergency requiring treatment within 6 hours.

\section{Competing interests: None declared.}

\section{References}

1. DeLamarter RB, Sherman JE, Carr JB. Cauda equina syndrome: neurologic recovery following immediate, early or late decompression. Spine 1992;16:1022-9.

2. Sayegh FE, Kapetanos GA, Symeonides PP, Anogiannakis G, Madentzidis M. Functional outcome after experimental cauda equina compression. J Bone Joint Surg [Br] 1997;79:670-4.

3. Kostiuk JP, Harrington I, Alexander D, Rand W, Evans D. Cauda equina syndrome and lumbar disc herniation. J Bone Joint Surg [Am] 1986;68:386-91.

4. Ahn UM, Buchowski JM, Ahn NU, Sieber A, Kostuik JP. Cauda equina syndrome secondary to lumbar disk herniation: a metaanalysis of surgical outcomes. Presented at the annual meeting of American Academy of Orthopaedic Surgeons, Anaheim, Calif., Feb. 4-8, 1999.

5. Lang DA, Neil-Dwyer G, Garfield J. Outcome after complex neurosurgery: the caregiver's burden is forgotten. J Neurosurg 1999;91:359-63.

6. Fitzpatrick R. Surveys of patient satisfaction: I - Important general considerations. BMJ 1991;302:887-9.

7. Chang HS, Makagawa H, Mizuno J. Lumbar herniated disc presenting with cauda equina syndrome. Long-term follow-up of four cases. Surg Neurol 2000;53:100-4.

8. Williamson C. The challenge of lay partnership. BMJ 1999;319: 721-2.

9. Gerszten PC. Outcomes research: a review. Neurosurg 1998;43:1146-56.

10. Ware JE Jr, Sherbourne CD. The MOS 36-item Short-Form Health Survey (SF-36): I. Conceptual framework and item selection. Med Care 1992;30:473-83.

11. Ware JE Jr, Snow KK, Kosinski M, Gandek B. SF-36 Health Survey: manual and interpretation guide. Boston: Nimrod Press; 1993.

12. Tandon PN, Sankaran B. Cauda equina syndrome due to lumbar disc prolapse. Indian J Orthop 1967;1:112-9.

13. Epstein NE, Hood DC. A comparison of surgeon's assessment to patient's self analysis (short form 36) after far lateral lumbar disc surgery. An outcome study. Spine 1997;22:2422-8.

14. Shapiro S. Cauda equina syndrome secondary to lumbar disc herniation. Neurosurgery 1993;32:743-7.
15. Kantz ME, Harris WJ, Levitsky K, Ware JE, Davies AR. Methods for assessing condition-specific and generic functional status outcomes after total knee replacement. Med Care 1992;30(5 Suppl):MS240-52.

16. Grevitt M, Khazim R, Webb J, Mulholland R, Shepperd J. The short form-36 health survey questionnaire in spine surgery. $\mathrm{J}$ Bone Joint Surg [Br] 1997;79:48-52.

17. Kardaun J. Acute complications in patients with surgical treatment of lumbar herniated discs. J Spine Disord 1990;3:30-8.

18. Choudhury AR, Taylor JC. Cauda equina syndrome in lumbar disc disease. Acta Orthop Scand 1980;51:493-9.

19. Parke WW, Gammell K, Rothman RH. Arterial vascularization of the cauda equina. J Bone Joint Surg [Am] 1981;63:53-62.

20. Wippold FJ 2nd, Smirniotopoulos JG, Pilgram TK. Lesions of the cauda equina: a clinical and pathology review from the Armed Forces Institute of Pathology. Clin Neurol Neurosurg 1997;99:229-34.

21. Jennett WB. A study of 25 cases of compression of the cause equina by prolapsed intervertebral discs. J Neurol Neurosurg Psychiatry 1956;19:109-16.

22. Aho A, Auranen A, Pesonen K. Analysis of cauda equina symptoms in patients with lumbar disc prolapse. Acta Chir Scand 1969;135:413-20.

23. Tay ECK, Chacha PB. Midline prolapse of a lumbar intervertebral disc with compression of the cauda equina. J Bone Joint Surg [Br] 1979;61:43-6.

24. Bonaroti EA, Welch WC. Posterior epidural migration of an extruded lumbar disc fragment causing cauda equina syndrome. Spine 1998;23:378-81.

25. Murrey DB, Hanley EN. Surgery for lumbar disc herniation: What are the choices? J Musculoskel Med 1999;16:39-45.

26. Frymoyer JW. Back pain and sciatica. N Engl J Med 1988;318: 291-300.

27. Coscia M, Leipzig T, Cooper D. Acute cauda equina syndrome. diagnostic advantage of MRI. Spine 1994;19:475-8.

28. Gibson JNA, Grant IC, Waddell G. Surgery for lumbar disc prolapse (Cochrane Review). In: The Cochrane Library, Issue 3, 1999. Oxford: Update Software.

29. Grane P, Tullberg T, Rydberg J, Lindgren L. Postoperative lumbar MR imaging with contrast enhancement. Comparisons between symptomatic and asymptomatic patients. Acta Radiologica 1996;37:366-72.

30. Shepard R. Diagnosis and prognosis of cauda equina syndrome produced by protrusion of lumbar disc. BMJ 1959;2:1434-9.

31. McLaren AC, Bailey SI. Cauda equina syndrome: a complication of lumbar discectomy. Clin Orthop 1986;204:143-9.

32. O'Laoire SA, Crockard HA, Thomas DG. Prognosis for sphincter recovery after operation for cauda equina compression owing to lumbar disc prolapse. BMJ 1981;282:1852-4.

33. Floman Y, Wiesel SW, Rothman RH. Cauda equina syndrome presenting as a herniated lumbar disk. Clin Orthop Rel Res 1980;147:235-7.

34. Nielsen B, de Nully M, Schmidt K, Hansen I. A urodynamic study of cauda equina syndrome due to lumbar disc herniation. Urol Int 1980;35:167-70.

35. Hellstrom P, Kortelainen P, Kontturi M. Late urodynamic findings after surgery for cauda equina by prolapsed intervertebral disk. J Urol 1986;135:308-12.

36. Kerr RS, Cadoux-Hudson TA, Adams CB. The value of accurate 
clinical assessment in the surgical management of the lumbar disc protrusion. J Neurol Neurosurg Psychiatry 1988;51:169-73.

37. Lafuente DJ, Andrew J, Joy A. Sacral sparing with cauda equina compression from central lumbar intervertebral collapse. J Neurol Neurosurg Psychiatry 1985;48:579-81.

38. Robinson R. Massive protrusions of lumbar discs. Br J Surg 1965;52:858-65.

39. Smith S, Leibrock L, Gelber B, Pierson E. Acute herniated nucleus pulposus with cauda equina compression syndrome following chemonucleolysis. J Neurosurg 1987;66:614-7.

40. Egger M, Schneider M, Smith GD. Spurious precision? Metaanalysis of observational studies. BMJ 1998;316:140-4.

41. Thompson SG, Pocock SJ. Can meta-analyses be trusted? Lancet 1991;338:1127-30.

42. Junge A, Dvorak J, Ahrens S. Predictors of bad and good outcomes of lumbar disc surgery: a prospective clinical study resulting in recommendations for screening to avoid bad outcomes. Spine 1995;20:460-8.
43. Junge A, Frohlich M, Ahrens S, Hasenbring M, Sandler A, Grob $\mathrm{D}$, et al. Predictors of bad and good outcomes of lumbar disc surgery: a prospective clinical study with 2 years' follow-up. Spine 1996;21:1064-5.

44. Bouchet C, Guillemin F, Briançon S. Nonspecific effects in longitudinal studies: impact on quality of life measures. Clin Epidemiol 1996;49:15-20.

45. Camilleri-Brennan J, Steele RJC. Measurement of quality of life in surgery. J R Coll Surg Edinb 1999;44:252-9.

46. Wood-Dauphinee S. Assessing quality of life in clinical research: From where have we come and where are we going? J Clin Epidemiol 1999;52:355-63.

Correspondence to: Dr. Mohit Bhandari, Department of Clinical Epidemiology and Biostatistics, McMaster University, 1200 Main St. W, Hamilton ON L8N 3Z5; 905 525-9140 x2825, fax 905 524-3841, bhandari@sympatico.ca

\section{Canadian Journal of Emergency Medicine Journal canadien de la médecine d'urgence}

\section{SUBSCRIPTION ORDER FORM}

Mail to: Canadian Association of Emergency Physicians

1785 Alta Vista Dr., Ste. 104

Ottawa ON K1G 3 Y6

Fax to: 613 523-0190

Name

Address

Address

City, Province

Postal Code

Phone

Fax

Price: Canada $\$ 50$ per year (four issues). United States and elsewhere, US\$50.

\section{Method of payment:}

Cheque enclosed ( )

Visa card no:

Expiry date

MasterCard no:

Expiry date

Please send me information on CAEP membership ( ) 